\title{
Z Jednoty filosofické
}

V podzimním semestru akademického roku 2017 se na Filozofické fakultě Masarykovy univerzity, v posluchárně Katedry filozofie A 11, konaly tyto přednášky:

Mgr. Filip Tvrdý, Ph.D. (Katedra filozofie, Filozofická fakulta Univerzity Palackého, Olomouc)

\section{Obrana epistemického paternalismu}

2. ř́jjna 2017

Problém demarkace vědy a pseudovědy byl jedním z hlavních zájmů analytické filozofie ve druhé polovině 20. století. V úvodu svého př́íspěvku stručně představím některá řešení tohoto problému, upozorním ale na obtíže spojené se snahou nalézt univerzální a apriorní kritérium, které by demarkaci zajistilo. Budu obhajovat tezi, že slibnějším prrístupem je hledání kognitivních mechanismů, na nichž je založeno přijetí pseudovědeckých a konspiračních teorií. Pomocí soudobé psychologie lze rozvinout epistemologii ctností, podle níž je klíčové zkoumat epistemický charakter myslících agentů.

Z její normativní povahy vyplývá otázka, jak nakládat s aktéry, jejichž epistemické schopnosti jsou natolik poškozeny, že jejich závěry nemohou být považovány za pravdivé a zdůvodněné. V liberálních demokraciích je považován za běžnou součást repertoáru politických praktik paternalismus, který brání jedincům rozhodovat se v protikladu k vlastním zájmům. Otázkou je, zdali přenést tento druh paternalismu i do epistemologie.

V závěru svého příspěvku budu obhajovat stanovisko, že současná informační exploze a nízká vědecká gramotnost veřejnosti způsobuje, že nějaká forma epistemického paternalismu je nezbytná. Pokud se nechceme vzdát standardů racionality a justifikace, musíme nově promyslet paternalistické důsledky naší normativní epistemologie. 
Prof. PhDr. Ing. Josef Šmajs, CSc. (Katedra podnikového hospodářství, Ekonomicko-správní fakulta MU, Brno)

\section{Implikace evoluční ontologie}

6. listopadu 2017

K podstatě evoluční ontologie. Její přírodovědecké implikace. Antropologic-

ké implikace. Kulturologické implikace. První intuitivní implikací ve smyslu uplatnění této ontologie na další oblasti filosofie, přírodních i společenských věd byla před dvaceti pěti lety kniha Ohrožená kultura. Tu před dvěma lety doplnila kniha Fenomén techniky a Ústava Země. Ohrožená kultura vznikala sice z přednášek pro Svobodnou Evropu, ale měla podtitul Od evoluční ontologie k ekologické politice. Dnes už vycházejí větší či menší práce dalších autorů inspirované touto obecnou teorií. Teprve v průběhu času se však utvářela vlastní obsahová struktura této nové ontologie. Dnes tuto procesuální ontologii charakterizují přibližně tyto hlavní kategorie: Př́roda, kultura, evoluce, informace, uspořádanost, systém, struktura.

Doc. PhDr. Marek Picha, Ph.D. (Katedra filozofie, Filozofická fakulta MU, Brno)

\section{Ignorance a obskurita}

20. listopadu 2017

Přinejmenším od dob raného novověku je znalost vnímána jako ústřední filozofické desideratum a panuje obecné přesvědčení, že klíčem k úspěšnému splnění cíle je rozvoj odpovídajících znalostí. V přednášce nebudu toto přesvědčení zpochybňovat, ale na vybraných prríkladech ukážu, jakou roli v takovém vidění světa hraje ignorance. Poukážu na různé podoby neznalosti, zdůrazním kladné stránky a užitečnost ignorance. 